\title{
Productive Traits of Broiler Chickens Fed Diets Containing Different Growth Promoters
}

Author(s)

Pelicano ERL

Souza PA de

Souza HBA de

Leonel FR

Zeola NMBL

Boiago MM

Faculdade de Ciências Agrárias e Veterinárias Departamento de Tecnologia

Campus de Jaboticabal - Unesp

\footnotetext{
Elizabete Regina Leone Pelicano

Departamento de Tecnologia

Faculdade de Ciências Agrárias e Veterinárias - Unesp

Via de Acesso Prof. Paulo D. Castellane, km 5 14.884-900 - Jaboticabal, SP

Telephone: (55) 1632092675 , ext. 245

Fax: (55) 1632092675

E-mail: erlpelicano@yahoo.com.br
}

Mail Address

\section{Keywords}

Broiler chickens, performance, prebiotics, probiotics.

\section{ABSTRACT}

This study evaluated the effect of different probiotics and prebiotics on the performance of broilers. One-day-old male broiler chicks from the Cobb strain $(n=1,260)$ were randomly distributed in a $3 \times 3$ factorial arrangement, considering 3 probiotics and 3 prebiotics sources. Nine treatments with 4 repetitions and 35 birds per parcel were used. The results showed that there was no influence of treatment on feed intake at the different rearing phases. Better weight gain $(p<0.05)$ was seen when diet was supplemented with the phosphorylated mannanoligosaccharide-based prebiotic (MOS) compared to diets without prebiotics. Feed conversion of birds fed diets with probiotics and prebiotics was better than feed conversion of birds not receiving such additives. Such better results were seen in the initial period (1 to 21 days), but not in the following period (1 to 35 days) or in the total period ( 1 to 42 days). Better rearing viability was seen when MOS was used together with organic acidifier when compared to the diets without prebiotic. Viability was worst when no prebiotics or probiotics were used. It was concluded that beneficial effects were seen in performance of birds at 21 days when the growth promoters were used, but not at 42 days of age. Nevertheless, there was better growth viability at 42 days of age when growth promoters were added.

\section{INTRODUCTION}

The continuous search for a maximum feed efficiency in modern poultry production has been considered a critical point in broiler rearing. Therefore, many additives have been used in the diets in order to improve digestion and promote better bird performance.

The use of antibiotics as growth promoters in animal feeding dates from the 50's, when the addition of subtherapeutic dosages of antibiotics resulted in great benefits for animal rearing, expressed as significant improvements in weight gain, feed conversion and viability. Nevertheless, few antibiotics may be used nowadays in animal feeding in Brazil and worldwide. Laws were instituted as a response to the indiscriminate use of antibiotics and consequent problems, such as development of resistant strains within groups of primary pathogenic or opportunistic bacteria (Fuller, 1989) and breakdown of the symbiosis between the animal and the desirable flora (Mulder, 1991). Furthermore, there were reports concerning the build-up of antibiotic residues in animal tissues that were later ingested by humans and caused resistance of human flora to such antibiotic, together with the appearance of cross-resistance to antibiotic therapy in humans and other animals. Thus, the poultry industry searched for alternatives that were economically viable due to the increasing restrictions to the use of antibiotics in animal diets by meat importers (mainly the European market) and international health organizations (FDA, 1988). 
Pelicano ERL, Souza PA de, Souza HBA de, Leonel FR, Zeola NMBL, Boiago MM

An alternative is the use of probiotics, prebiotics and symbiotics (feeding probiotic microorganisms together with prebiotic substances), which might contribute due to the development of beneficial microorganisms in the gastrointestinal tract (Pelicano et al., 2002). Consequently, there would be an improvement of the intestinal environment for the processes of digestion and absorption of nutrients. It is worth noting that such products would not be substitutes for antibiotics, but rather an efficient and economic alternative to these. Consequently, antibiotics might be used only when they are really needed.

Many researchers have reported improvement of productive and qualitative indexes with the utilization of such additives (Iji \& Tivey, 1998; Jin et al., 1998, Sims et al., 1998; Sogaard \& Suhr-Jessen, 1999; Besnard et al., 2000; Maiorka et al., 2001, Campos et al., 2002; Laurentiz et al., 2003), whereas others found no improvement (Araújo et al., 2000; Loddi et al., 2000; Pelicano et al., 2003a; Pelicano et al., 2003b; Pelicano et al., 2004).

Since the efficacy of such products has not been proved yet, their use as alternatives to traditional growth promoters in the future must be grounded on further investigations. Nevertheless, conditions must be established so that microorganisms survive at beneficial levels until they reach the host gut and are consumed (USDEC, 2002).

The present study evaluated the effect of using different probiotics and prebiotics on the performance (feed intake, weight gain, feed conversion and viability) of broiler chickens.

\section{MATERIAL AND METHODS}

\section{Experimental Design and Treatments}

The experiment was carried out at Faculdade de Ciências Agrárias e Veterinárias, UNESP, Campus de Jaboticabal, from October until December 2003. Male broiler chicks $(1,260)$ from Cobb strain were vaccinated against Marek's disease in the hatchery and against Newcastle and Gumboro diseases at the poultry house. Standard commercial management of broiler birds was used throughout the experiment. The birds were distributed in 36 pens (35 birds/pen), measuring 3.20 $\mathrm{m} \times 1.46 \mathrm{~m}$ (final density of 8 birds $/ \mathrm{m}^{2}$ ). Wood shavings were used as litter material $( \pm 5 \mathrm{~cm})$. In the first weeks, chick feeders and pressure drinkers were used and infrared lamps provided heating. After the second week, initial equipment was changed to $20-\mathrm{kg}$ hanging tube feeders and bell type drinkers.
Productive Traits of Broiler Chickens Fed Diets Containing Different Growth Promoters

Ambient temperature and relative humidity were recorded daily, and adequate curtain and fan management was performed to assure environment comfort to the birds. Feed and water were given ad libitum.

In order to prevent cross-contamination of diets with microorganisms, diets were handled one at a time and with separate scoops. Besides, separate cleaning material was used for the drinkers of different treatments and disposable plastic booties were used when entering each pen, so as to prevent microbial contamination between treatments.

Birds were distributed in a completely randomized experimental design and $3 \times 3$ factorial arrangement. There were 3 probiotic levels (control, probiotic 1 and probiotic 2), and 3 prebiotic levels (control, prebiotic 1 and prebiotic 2) in the diets, resulting in 9 treatments and 4 repetitions of 35 birds each.

Commercial probiotics and prebiotics were used according to the manufacturer's instructions. Probiotic 1 was based on Bacillus subtilis and was added to the diet at $150 \mathrm{~g} / \mathrm{ton}$, from 1 to 42 days of age. Probiotic 2 was based on Lactobacillus acidophilus and casei, Streptococcus lactis and faecium, Bifidobacterium bifidum and Aspergillus oryzae and was added to the diet at $1 \mathrm{~kg} / \mathrm{ton}$, from 1 to 42 days of age. Prebiotics, on the other hand, were added at different concentrations in the different evaluated periods. Prebiotic 1, based on phosphorylated mannanoligosaccharide (MOS) and organic acidifier, was added to the diet at $2 \mathrm{~kg} /$ ton in the initial phase (1 - $21 \mathrm{~d}$ ) and $1.5 \mathrm{~kg} /$ ton until slaughter age (22 - $42 \mathrm{~d}$ ). Prebiotic 2 was a MOS-based prebiotic and was added to the diet at $1 \mathrm{~kg} /$ ton in the initial phase $(1-21 \mathrm{~d})$ and $0.5 \mathrm{~kg} /$ ton until slaughter age ( 22 to $42 \mathrm{~d}$ ).

\section{Experimental diet}

Birds were given food and water ad libitum throughout the experimental period, which was divided in three phases. Starting diets (1-21d) contained $3,000 \mathrm{kcal} / \mathrm{kg}$ metabolizable energy, $21.4 \%$ crude protein, $1.263 \%$ lysine, $0.561 \%$ methionine, $0.960 \%$ $\mathrm{Ca}$ and $0.450 \%$ available P. Growing diets (22-35d) had $3,100 \mathrm{kcal} / \mathrm{kg}$ metabolizable energy, $19.3 \%$ crude protein, $1.156 \%$ lysine, $0.514 \%$ methionine, $0.874 \%$ $\mathrm{Ca}$ and $0.406 \%$ available $\mathrm{P}$, whereas finishing diets (36-42d) had levels of 3,200 kcal/kg metabolizable energy, $18 \%$ crude protein, $1.040 \%$ lysine, $0.445 \%$ methionine, $0.800 \% \mathrm{C}$ a and $0.365 \%$ available P. Other nutrient levels were according to those recommended by Rostagno et al. (2000). 
Pelicano ERL, Souza PA de, Souza HBA de, Leonel FR, Zeola NMBL, Boiago MM

\section{Evaluated parameters}

Performance data were recorded in the periods from 1 to 21,1 to 35 and 1 to 42 days of age. Feed intake was determined for each repetition as the difference between the amount of feed supplied and the remaining feed at the end of each experimental period, and weight gain was calculated as the difference between the final and initial bird weight. Feed conversion was determined as the ratio between feed intake and weight gain at each phase of the experimental period and viability was determined as the number of birds produced at 42 days of age divided by the initial number of chicks $\times 100$.

\section{Sstatistical Analysis}

Statistical analysis was performed using the software Estat 2.0 (1992), and differences between treatment means were evaluated by Tukey's test at a significance level of $5 \%\left(H_{0} p<0.05\right)$.

\section{RESULTS AND DISCUSSION}

There was no influence of treatments on the feed intake of broilers fed diets containing pre- or probiotics (Table 1), corroborating previously reported results (Mohan et al., 1996; Maiorka et al., 2001; Pelicano et al., 2003b).

Table 2 shows that there were no differences in weight gain of birds at 21, 35 and 42 days of age when different probiotics were added to the diets. It is worth noting that these results may reflect the good husbandry that the birds were submitted to, resulting in a low sanitary challenge condition. Under conditions of minimum stress, probiotics may produce results that are not so evident (Fox, 1988; Franceschi \& Stocker, 1989; Dale, 1992; Maruta, 1993). Similar results were reported by Jernigam \& Miles (1985), Jiraphocakul et al. (1990) and Loddi et al. (2000). Nevertheless, according to Tournut (1998), product efficacy depends totally on the quantity and characteristics of the microorganism strains that are used during probiotic production. Therefore, it is difficult to compare results from such studies and the present study.

The use of the prebiotics based on phosphorylated mannanoligosaccharide (MOS) resulted in better weight gain at 21 days of age $(p<0.05)$ when compared to the control group (Table 2 ). Such results are corroborated by those reported previously by Toledo et al. (2003). According to Spring et al. (2000), MOS from the cellular wall of yeasts may block binding sites of pathogenic bacteria on the intestinal mucosa, decreasing intestinal injury, and consequently, cellular
Productive Traits of Broiler Chickens Fed Diets Containing Different Growth Promoters

turnover. This would result in better utilization of diet feedstuffs and better performance.

Table 1 - Feed intake of broilers fed probiotics and prebiotics in the diet at different rearing phases.

\begin{tabular}{|c|c|c|c|}
\hline \multirow{2}{*}{$\begin{array}{l}\text { Evaluated } \\
\text { Parameter }\end{array}$} & \multicolumn{3}{|c|}{ Feed intake (kg) } \\
\hline & 1 to 21 days & 1 to 35 days & 1 to 42 days \\
\hline \multicolumn{4}{|c|}{ Probiotics in the diet (PRO) } \\
\hline Control & $1.16^{\mathrm{a}}$ & $3.24^{\mathrm{a}}$ & $4.54^{\mathrm{a}}$ \\
\hline Probiotics $1^{(1)}$ & 1.1 & $d$ & $15^{\mathrm{a}}$ \\
\hline Probiotics $2^{(2)}$ & $1.15^{\text {a }}$ & 3. & $4.53^{a}$ \\
\hline F Test & $1.38 \mathrm{~ns}$ & $0 \mathrm{~ns}$ & $1.95 \mathrm{~ns}$ \\
\hline MSL & 0.03 & 0.08 & 0.12 \\
\hline \multicolumn{4}{|c|}{ Prebiotics in diet (PRE) } \\
\hline Control & $1.14^{\mathrm{a}}$ & $3.22^{\mathrm{a}}$ & $4.49^{a}$ \\
\hline Prebiotics $1{ }^{(3)}$ & $1.15^{\mathrm{a}}$ & a & $3^{a}$ \\
\hline Prebiotics $2^{(4)}$ & $1.15^{a}$ & a & $4.49^{a}$ \\
\hline F Test & $0.13 \mathrm{~ns}$ & $0.11 \mathrm{~ns}$ & $0.51 \mathrm{~ns}$ \\
\hline MSD (\%) & 0.03 & 0.08 & 0.12 \\
\hline PRO $\times$ PRE & $1.79 \mathrm{~ns}$ & $0.66 \mathrm{~ns}$ & $1.28 \mathrm{~ns}$ \\
\hline CV $(\%)$ & 2.93 & 2.56 & 2.62 \\
\hline \multicolumn{4}{|c|}{$\begin{array}{l}\text { a - Within the same factor, means followed by similar letters in the } \\
\text { column are similar ( } p>0.05 \text { ) by Tukey's test. Test F: ns, non-significant } \\
\text { MSD - Minimal Significant Difference. CV - Coefficient of Variation } \\
1 \text { - Probiotics based on Bacillus subtilis added to the diet throughout } \\
\text { the experimental period. } 2 \text { - Probiotics based on Lactobacillus } \\
\text { acidophilus and casei, Streptococcus lactis and faecium, } \\
\text { Bifidobacterium bifidum and Aspergillus oryzae added to the diet } \\
\text { throughout the experimental period. } 3 \text { - Prebiotics based on MOS } \\
\text { and organic acidifier added to the diet throughout the experimental } \\
\text { period. } 4 \text { - Prebiotics based on MOS added to the diet throughout } \\
\text { the experimental period. }\end{array}$} \\
\hline
\end{tabular}

Table $\mathbf{2}$ - Weight gain of broilers fed probiotics and prebiotics in the diet at different rearing phases.

\begin{tabular}{|c|c|c|c|}
\hline \multirow{2}{*}{$\begin{array}{l}\text { Evaluated } \\
\text { Parameter }\end{array}$} & \multicolumn{3}{|c|}{ Weight gain $(\mathbf{k g})$} \\
\hline & 1 to 21 days & 1 to 35 days & 1 to 42 days \\
\hline \multicolumn{4}{|c|}{ Probiotics in diet (PRO) } \\
\hline Control & $0.84^{a}$ & $1.94^{\mathrm{a}}$ & $2.48^{a}$ \\
\hline Probiotics 1 (1) & $0.84^{a}$ & $1.92^{\mathrm{a}}$ & $2.43^{a}$ \\
\hline Probiotics 2 (2) & $0.86^{a}$ & $1.97 \mathrm{a}$ & $2.51^{\mathrm{a}}$ \\
\hline Test & $2.39 \mathrm{~ns}$ & $1.50 \mathrm{~ns}$ & $2.17 \mathrm{~ns}$ \\
\hline MSD (\%) & 0.02 & 0.08 & 0.10 \\
\hline \multicolumn{4}{|c|}{ Prebiotics in diet (PRE) } \\
\hline Control & $0.83^{b}$ & 1.92 a & $2.45^{\mathrm{a}}$ \\
\hline Prebiotics 1 (3) & $0.85 a b$ & a & $2.50^{\mathrm{a}}$ \\
\hline Prebiotics $2^{(4)}$ & .8 & a & $2.48^{a}$ \\
\hline Test & 4.29 * & $1.43 \mathrm{~ns}$ & $0.80 \mathrm{~ns}$ \\
\hline MSD (\%) & 0.02 & 0.08 & 0.10 \\
\hline PRO $\times$ PRE & $1.31 \mathrm{~ns}$ & $1.52 \mathrm{~ns}$ & $1.81 \mathrm{~ns}$ \\
\hline CV $(\%)$ & 2.59 & 3.95 & 3.87 \\
\hline \multicolumn{4}{|c|}{$\begin{array}{l}\text { a,b-Within the same factor, means followed by similar letters in the } \\
\text { column are similar ( } p>0.05 \text { ) by Tukey's Test. Test F: ns, non-significant; } \\
{ }^{*} \mathrm{p}<0.05 \text {. MSD - Minimal Significant Difference. CV - Coefficient of } \\
\text { Variation. } 1 \text {-Probiotics based on Bacillus subtilis added to the diet } \\
\text { throughout the experimental period. } 2 \text {-Probiotics based on } \\
\text { Lactobacillus acidophilus and casei, Streptococcus lactis and faecium, } \\
\text { Bifidobacterium bifidum and Aspergillus oryzae added to the diet } \\
\text { throughout the experimental period. } 3 \text { - Prebiotics based on MOS } \\
\text { and organic acidifier added to the diet throughout the experimental } \\
\text { period. } 4 \text { - Prebiotics based on MOS added to the diet throughout } \\
\text { the experimental period. }\end{array}$} \\
\hline
\end{tabular}


Although MOS-based prebiotic resulted in better weight gain at 21 days of age, such findings were not seen at 35 and 42 days of age. It is known that the stress level to which birds are submitted influences the biological response to the addition of prebiotics to the diet (Silva \& Nornberg, 2003). Therefore, if the birds are under non-stressful conditions, it is supposed that the microbiota is in equilibrium. In other words, the response of the animal is very similar, with or without adding prebiotics (Mosenthin \& Bauer, 2000). It is also worth noting that the absence of prebiotic effects might be related to the kind of feedstuffs used in the diet as well. The greater percentage of animal diets is comprised of ingredients derived from grains of cereals (corn) and of oleaginous plants (soybean meal). The chemical composition of such ingredients comprises different levels of non-starch polysaccharides (NSP) and non-digestible oligossacharides (NDOs), which are indigestible compounds, although potentially fermentable by intestinal flora. Therefore, it can be supposed that the absence of response when a prebiotic is added to the diet may be due to a "diluting" effect of the NSPs and NDOs present in the ingredients. In many situations, the levels of such compounds in the grains and their by-products are much higher than the levels added to the diet as prebiotics (Silva \& Nornberg, 2003).

Different results have been reported by Macari \& Maiorka (2000) and Santin et al. (2001), in which 0.2\% of cellular wall from Saccharomyces cerevisiae (MOS from yeast cellular wall) increased significantly weight gain in comparison to control animals.

Better feed conversion at 21 days-old was seen in birds fed diets added with probiotics and prebiotics when compared to the groups that received no additives (Table 3 ). Similar results were seen when probiotics (Bacillus subtilis) and prebiotics ( $0.2 \%$ of yeast cellular wall) were added to the diet of 21 days-old broiler chickens (Maiorka et al., 2001; Santin et al., 2001, respectively). Nevertheless, no difference was observed in feed conversion in the subsequent periods (35 and 42 days of age), demonstrating that the beneficial effect of such products was present only in the initial period.

Better viability $(p<0.05)$ was obtained with prebiotics based on MOS and organic acidifier (Table 4) compared to the diets with no prebiotics. According to Radecki \& Yokoyama (1991), the fermentation of prebiotics added to the diets stimulates the growth and stability of specific microbial populations that produce organic acids. Therefore, there is a decrease in the lumen $\mathrm{pH}$, which, associated to other antibacterial substances and

enzymes produced by the same flora, inhibits acidic $\mathrm{pH}$ sensitive pathogenic microorganisms such as Escherichia coli, Clostridium sp and Salmonella. It can be thus deduced that higher viability was seen due to a double production of organic acids (by the flora and the acid added in the diet with the prebiotics), contributing to a more effective reduction in intestinal $\mathrm{pH}$.

Table 3 - Feed conversion of broilers fed probiotics and prebiotics in the diet at different rearing phases.

\begin{tabular}{|c|c|c|c|}
\hline \multirow{2}{*}{$\begin{array}{l}\text { Evaluated } \\
\text { Parameter }\end{array}$} & \multicolumn{3}{|c|}{ Feed Conversion } \\
\hline & $\begin{array}{l}1 \text { to } 21 \text { days } \\
\text { Probiotic }\end{array}$ & $\begin{array}{l}1 \text { to } 35 \text { days } \\
\text { in diet (PRO) }\end{array}$ & 1 to 42 days \\
\hline Control & $1.38^{a}$ & $1.67^{a}$ & $1.83^{a}$ \\
\hline Probiotics $1^{(1)}$ & $1.35^{b}$ & $1.68^{a}$ & $1.83^{a}$ \\
\hline Probiotics $2^{(2)}$ & $1.34^{b}$ & $1.64^{a}$ & $1.80^{a}$ \\
\hline F Test & $8.92 * *$ & $2.67 \mathrm{~ns}$ & $1.71 \mathrm{~ns}$ \\
\hline MSD (\%) & 0.02 & 0.04 & 0.04 \\
\hline \multicolumn{4}{|c|}{ Prebiotics in diet (PRE) } \\
\hline Control & $1.38^{\mathrm{a}}$ & $1.68^{a}$ & $1.83^{a}$ \\
\hline Prebiotics 1 (3) & $1.35^{b}$ & $1.67^{\mathrm{a}}$ & $1.81^{\mathrm{a}}$ \\
\hline Prebiotics 2 & $1.34^{b}$ & $1.64^{\mathrm{a}}$ & $1.81^{\mathrm{a}}$ \\
\hline F Test & $5.66 * *$ & $3.32 \mathrm{~ns}$ & $0.86 \mathrm{~ns}$ \\
\hline MSD (\%) & 0.02 & 0.04 & 0.04 \\
\hline PRO $\times$ PRE & $1.39 \mathrm{~ns}$ & $1.50 \mathrm{~ns}$ & $1.37 \mathrm{~ns}$ \\
\hline CV $(\%)$ & 1.79 & 2.27 & 2.28 \\
\hline
\end{tabular}

$\mathrm{a}, \mathrm{b}-$ Within the same factor, means followed by similar letters in the column are similar ( $p>0.05)$ by Tukey's Test. Test F: ns, non-significant; ** $p<0.01$. MSD - Minimal Significant Difference. CV - Coefficient of Variation. 1 - Probiotics based on Bacillus subtilis added to the diet throughout the experimental period, 2 - Probiotics based on Lactobacillus acidophilus and casei, Streptococcus lactis and faecium, Bifidobacterium bifidum and Aspergillus oryzae added to the diet throughout the experimental period. 3 - Prebiotics based on MOS and organic acidifier added to the diet throughout the experimental period. 4 - Prebiotics based on MOS added to the diet throughout the experimental period.

Table 4 - Viability of broilers fed probiotics and prebiotics in the diet from 1 to 42 days of age.

\begin{tabular}{|c|c|}
\hline $\begin{array}{l}\text { Evaluated } \\
\text { Parameter }\end{array}$ & $\begin{array}{l}\text { Viability (\%) } \\
1 \text { to } 42 \text { days }\end{array}$ \\
\hline \multicolumn{2}{|c|}{ Probiotics in diet (PRO) } \\
\hline Control & 96.19 a \\
\hline Probiotics 1 (1) & $96.67^{a}$ \\
\hline Probiotics 2 (2) & $98.33^{\text {a }}$ \\
\hline F Test & $2.31 \mathrm{~ns}$ \\
\hline MSD (\%) & 2.60 \\
\hline \multicolumn{2}{|c|}{ Prebiotics in diet (PRE) } \\
\hline Control & $95.48^{b}$ \\
\hline Prebiotics 1 (3) & 98.09 a \\
\hline Prebiotics 2 & $97.62 a b$ \\
\hline F Test & $3.55 *$ \\
\hline MSD (\%) & 2.60 \\
\hline PRO $\times$ PRE & $3.03 *$ \\
\hline CV $(\%)$ & 2.64 \\
\hline \multicolumn{2}{|c|}{$\begin{array}{l}\text { a,b - Within the same factor, means followed by similar letters in the } \\
\text { column are similar (p>0.05) by Tukey's Test. Test F: ns, non-significant; } \\
\text { * p }<0.05 \text {. MSD - Minimal Significant Difference. CV - Coefficient of } \\
\text { Variation. } 1 \text {-Probiotics based on Bacillus subtilis added to the diet } \\
\text { throughout the experimental period, } 2 \text { - Probiotics based on } \\
\text { Lactobacillus acidophilus and casei, Streptococcus lactis and faecium, } \\
\text { Bifidobacterium bifidum and Aspergillus oryzae added to the diet } \\
\text { throughout the experimental period, } 3 \text {-Prebiotics based on MOS } \\
\text { and organic acidifier added to the diet throughout the experimental } \\
\text { period. } 4 \text { - Prebiotics based on MOS added to the diet throughout } \\
\text { the experimental period. }\end{array}$} \\
\hline
\end{tabular}


There was a significant interaction between the factors (Table 5). The utilization of diets containing probiotics and prebiotics enabled better viability, so that the inverse relationship also occurred. Such results may be attributed to a possible improvement in the immune system of the birds that was induced by the growth promoters. The immunological status of the host is directly related to the intestinal flora, since the antigenic load resulting from such bacteria induce stimulation of the immune system (Perdigon et al., 1993; Tannok, 1998; Leedle, 2000). According to Savage et al. (1996), the utilization of MOS in turkey diets increased IgA levels in $25 \%$.

Table $\mathbf{5}$ - Interaction effects (PRO x PRE) for viability of broiler chickens at 42 days of age.

\begin{tabular}{|c|c|c|c|}
\hline \multirow{2}{*}{$\begin{array}{l}\text { Prebiotics in diet } \\
\text { (PRE within PRO) }\end{array}$} & \multicolumn{3}{|c|}{ Probiotics in diet (PRO within PRE) } \\
\hline & Control & Probiotics $1^{(1)}$ & Probiotics $2^{(2)}$ \\
\hline Control & $92.15 \mathrm{Bb}^{*}$ & $97.14 \mathrm{Aa}$ & $97.14 \mathrm{Aa}$ \\
\hline Prebiotics 1 (3) & $97.86 \mathrm{Aa}$ & $97.86 \mathrm{Aa}$ & $98.57 \mathrm{Aa}$ \\
\hline Prebiotics $2^{(4)}$ & $98.57 \mathrm{Aa}$ & $95.00 \mathrm{Aa}$ & $99.29 \mathrm{Aa}$ \\
\hline
\end{tabular}

* - Means followed by similar capital (small) letters within the rows (columns) are similar ( $p>0.05)$ by Tukey's test. 1 - Probiotics based on Bacillus subtilis added to the diet throughout the experimental period. 2 -Probiotics based on Lactobacillus acidophilus and casei, Streptococcus lactis and faecium, Bifidobacterium bifidum and Aspergillus oryzae added to the diet throughout the experimental period. 3 - Prebiotics based on MOS and organic acidifier added to the diet throughout the experimental period. 4 - Prebiotics based on MOS added to the diet throughout the experimental period.

\section{CONCLUSIONS}

In the present study, beneficial effects were seen in performance of birds when the growth promoters were used at 21 days but not at 42 days of age. Nevertheless, there was better growth viability at 42 days of age when growth promoter were added.

\section{REFERENCES}

Araújo LF, Junqueira OM, Araújo CSS, Laurentiz AC, Sakomura NK, Casartelli EM. Antibiótico e probiótico para frangos de corte no período de 24 a 41 dias de idade. In: $37^{a}$ Reunião Anual da SBZ; 2000; Viçosa, Minas Gerais. Brasil. CD-ROM.

Besnard J, Auclair E, Larbier M. Effect of yeast supplementation on productive parameters of turkeys. In: World's Poultry Science Congress; 2000; Montreal, Canadá. CD-ROM.

Campos DMB, Faria Filho DE, Pinheiro JCA, Abe PT, Gadelha AC, Furlan RL, Macari M. Níveis de inclusão de probiótico (Bacillus subtilis) sobre o desempenho de frangos de corte. In: Conferência Apinco de Ciência e Tecnologia Avícolas; 2002; Campinas, São Paulo. Brasil. p.36.
Dale N. Probióticos para aves. Avicultura Profesional 1992; 10:8889.

ESTAT 2.0. Sistema de Análise Estatística. Jaboticabal(SP): Polo Computacional - Departamento de Ciências Exatas: UNESP; 1992.

FDA - Food And Drug Administration. Office on Compliance Guide; 1998. n० 7126.41 .

Fox SM. Probiotics: intestinal inoculants for production animals. Veterinary Medicine 1988; 83:806-830.

Franceschi M, Stocker GJ. Probioticos en producción avicola. Revision de um nuevo enfoque terapeutico. Veterinaria Argentina 1989; 6: 708-712.

Fuller R. Probiotics in man and animals. A review. Journal of Applied Bacteriology 1989; 66:365-378.

Iji PA, Tivey DR. Natural and synthetic oligosaccharides in broiler chicken diets. World's Poultry Science Journal 1998; 53:351-368.

Jernigan MA, Miles RD. Probiotics in poultry nutrition - A Review World's. Poultry Science 1985; 41:99-107.

Jin LZ, Ho YM, Abdullah N, Jalaludin S. Growth performance, intestinal microbial populations, and serum cholesterol of broilers fed diets containing Lactobacillus cultures. Poultry Science 1998; 77:1259-1265.

Jiraphocakul S, Sullivan TW, Shahani KM. Influence of a dried Bacillus subtilis culture and antibiotics on performance and intestinal microflora in turkey. Poultry Science 1990; 69:1966-1973.

Laurentiz AC, Lucas Jr. J, Araújo LF, Maiorka A, Borges AS, Penha Filho RAC, Moraes VMB. Efeito da adição de probiótico e da altura da cama sobre o desempenho de frangos de corte criados em diferentes temperaturas ambiente. In: 40 Reunião Anual da SBZ; 2003; Santa Maria, Rio Grande do Sul. Brasil. CD-ROM.

Leedle J. Probiotics and DFMs - mode of action in the gastrointestinal tract. In: Simpósio Sobre Aditivos Alternativos na Produção Animal; 2000; Campinas, São Paulo, Brasil. p. 25-40.

Loddi MM, Gonzales E, Takita TS, Mendes AA, Roça RO. Uso de probiótico e antibiótico sobre o desempenho, o rendimento e a qualidade da carcaça de frangos de corte. Revista Brasileira de Zootecnia 2000; 29(4):1124-1131.

Macari M, Maiorka A. Função gastrintestinal e seu impacto no rendimento avícola. In: Conferência Apinco de Ciência e Tecnologia Avícolas; 2000; Campinas, São Paulo, Brasil. v.2. p. 161-174.

Maiorka A, Santin E, Sugeta SM, Almeida JC, Macari M. Utilização de prebióticos, probióticos ou simbióticos em dietas para frangos. Revista Brasileira de Ciência Avícola 2001; 3 (1):75-82.

Maruta K. Probióticos e seus benefícios. In: Conferência Apinco de Ciência e Tecnologia Avícolas; 1993; Santos, São Paulo. Brasil. p. 203-19.

Mohan B, Kadirvel R, Natarajan A, Bhaskaran M. Effect of probiotic 
supplementation on growth, nitrogen utilization and serum cholesterol in broilers. British Poultry Science 1996; 37:395-401.

Mosenthin R, Bauer E. The potential use of prebiotics in pig nutrition. In: International Symposium on Recent Advances in Animal Nutrition; 2000; Seoul. Corea do Sul. p. 515-528.

Mulder RWAW. Probiotics as a tool against Salmonella contamination. Misset World Poultry 1991; 7:36-37.

Pelicano ERL, Souza PA, Souza HBA. Prebióticos e Probióticos na nutrição de aves. Ciências Agrárias e da Saúde 2002; 2(1):59-64.

Pelicano ERL, Souza PA, Souza HBA, Oba A, Norkus EA, Kodawara LM, Lima TMA. Effect of different probiotics on broiler carcass and meat quality. Brazilian Journal of Poultry Science 2003a; 5(3):207214.

Pelicano ERL, Souza PA, Souza HBA, Oba A, Norkus EA, Kodawara LM, Lima TMA. Desempenho zootécnico de frangos de corte alimentados com dietas contendo diferentes probióticos. In: 40a Reunião Anual da SBZ; 2003b; Santa Maria, Rio Grande do Sul. Brasil. CD-ROM.

Pelicano ERL, Souza PA, Souza HBA, Oba A, Zeola NMBL, Boiago MM, Scatolini AM, Bertanha VA. Efeito do uso de probióticos e/ou prebióticos sobre o rendimento de carcaça de frangos de corte. In: Conferência Apinco de Ciência e Tecnologia Avícolas; 2004; Santos, São Paulo. Brasil. p.18

Perdigon G, Alvarez S, Medici M, Holgado AAPR. Influence of the use of Lactobacillus casei as an oral adjuvant on the levels of secretory immunoglobulin A during an infection with Salmonella typhimurium. Food Agriculture Immunology 1993; 5:27-37.

Radecki SY, Yokoyama MT. Intestinal bacteria and their influence on swine nutrition. In: Miller, ER, Duane, EU, Lewis, AJ. Swine nutrition. Boston (MA): Butterworth-Heinemann; 1991. p. 439447.

Rostagno HS, Albino LFT, Donzele JL, Gomes PC, Ferreira AS, Oliveira RF, Lopes DC. Tabelas brasileiras para aves e suínos: composição de alimentos e exigências nutricionais. Viçosa(MG): Horacio Rostagno; 2000. $141 \mathrm{p}$.

Santin E, Maiorka A, Macari M, Grecco M, Sanchez JC, Okada TM, Myasaka AM. Performance and intestinal mucosa development of broiler chickens fed diets containing Saccharomyces cerevisiae cell wall. Journal Applied Poultry Research 2001; 10:236-244.

Savage TF, Cotter PF, Zakrewska El. Effect of feeding a mannanoligosaccharide on immunoglobulin, plasma IgG and bile IgA of Wrolstad MW male turkey. Poultry Science 1996; 75 (Supplement 1):143.

Silva LP, Nornberg JL. Prebióticos na nutrição de não-ruminantes. Ciência Rural 2003; 33 (5):983-990.

Sims MD, Spring $P$, Sefton AE. Effect of mannanoligosaccharides on performance of commercial broiler chickens. Poultry Science 1998; 77 (Supplement 1):89.
Sogaard H, Suhr-Jessen T. Microbials for feed: Beyond lactic acid bacteria. Feed International 1999; 11(1):32-38.

Spring P. Yeast's secret weapon aids animal production. In: Simpósio Sobre Aditivos Alternativos na Nutrição Animal; 2000; Campinas, São Paulo. Brasil. p. 41-50.

Tannock GW. Studies of the intestinal microflora: a prerequisite for the development of probiotics. International Dairy Journal 1998; 8:527-533.

Toledo RS, Rostagno HS, Albino LFT, Carvalho DCO, Oliveira JE, Dionizio MA. Efeito de prebióticos e milhos de diferente qualidade nutricional sobre o desempenho de frangos de corte na fase inicial. In: 40a Reunião Anual da SBZ; 2003, Santa Maria, Rio Grande do Sul. Brasil. CD-ROM.

Tournut JR. Probiotics. In: 35 a REUNIÃO ANUAL DA SBZ; 1998; Botucatu, São Paulo, Brasil. p. 179-199.

USDEC. Probióticos: a chave dos funcionais; 2002, 5(1):1-7. 